\title{
MODEL PEMBINAAN AKHLAK MULIA DALAM MENJAGA DAN MENINGKATKAN DISIPLIN KEBERSIHAN DI PONDOK PESANTREN AL-BASYARIYAH BANDUNG
}

\author{
Dini Rinjani*, \\ Endis Firdaus, Elan Sumarna \\ Program Studi Ilmu Pendidikan Agama Islam \\ Fakultas Pendidikan Ilmu Pengetahuan Sosial, Universitas Pendidikan Indonesia \\ *E-mail : dini.rinjani@student.upi.edu
}

\begin{abstract}
ABSTRAK
Pembinaan akhlak merupakan tumpuan perhatian utama dalam Islam.Hal ini dapat dilihat dari salah satu misi kerasulan nabi Muhammad SAW yang utama ialah untuk menyepurnakan akhlak yang mulia.Dalam salah satu Hadis nya beliau menegasakan bahwa "sesungguhnya aku (Muhammad) diutus untuk menyempurnakan akhlak mulia" (HR. Ahmad).Untuk mendalami pembinaan akhlak khususnya akhlak terhadap kebersihan perlu adanya analisa yang mendalam mengenai Model Pembinaan Akhlak Mulia dalam Menjaga dan Meningkatkan Disiplin Kebersihan, salah satunya yang diterapkan di Pondok Pesantren Al-Basyariyah Bandung.Penelitian ini bertujuan untuk mendeskripsikan sistem Pembinaan disiplin kebersihan Pondok Pesantren Al-Basyariyah, perencanaan disiplin kebersihan, pelaksanaan disiplin kebersihan Pondok, Komponen-komponen disiplin kebersihan serta Hambatan dan Hasil Evaluasi Pembinaan Disiplin Kebersihan.Penelitian ini menggunakan pendekatan kualitatif dengan metode deskriptif.Alasan menggunakan metode ini ialah untuk mendeskripsikan pembinaan akhlakdalam menjaga dan meningkatkan disiplin kebersihan di Pondok Pesantren Al-Basyariyah Bandung.Dalam pengumpulan data peneliti menggunakan tiga teknik yaitu observasi, wawancara, dan studi dokumentasi.Pondok melaksanakan pembinaan kebersihan dengan perencanaan yang tertuang di dalam peraturan kebersihan yang dibuat oleh pengasuh dan pengurus pondok, pelaksanaan disiplin kebersihan dilaksanakan setiap hari dari pagi, siang dan malam hari.Komponen yang ada dalam menjalankan kebersihan ialah, adanya santri, peraturan, pelaksanaan dan sarana prasarana.Hambatan yang dirasakan dalam menjalankan disiplin kebersihan meliputi kesadaran seluruh santru terhadap pentingnya kebersihan.Sistem evaluasi yang dilaksanakan dari pembinaan disiplin kebersihan di Pondok Pesantren AlBasyariyah dilaksanakan sebanyak dua kali.Pertama, evaluasi dilaksanakan setiap minggunya.Kedua, evaluasi dilaksanakan satu tahun sekali dalam Laporan Pertanggung Jawaban OSPA.
\end{abstract}

Kata kunci: Pembinaan Akhlak; Disiplin Kebersihan; Pondok Pesantren Al-Basyariyah. 


\section{PENDAHULUAN}

Pembinaan merupakan proses membina sebagai usaha tindakan dan kegiatan yang dilakukan secara efisien dan efektif untuk memperoleh hasil yang lebih baik, Pembinaan merupakan suatu kegiatan yang mempertahankan dan menyempurnakan apa yang telah ada. Melaksanakan suatu rangkaian kegiatan yang dilaksankan secara rutin serta mengevaluasi kegiatan tersebut menjadi kegitan yang semakin baik(Azhari, 2012, hal. 21).

Pembinaan akhlak merupakan tumpuan perhatian utama dalam Islam.Hal ini dapat dilihat dari salah satu misi kerasulan nabi Muḥammad SAW yang utama ialah untuk menyemurnakan akhlak yang mulia. Dalam salah satu Hadis nya beliau menegasakan

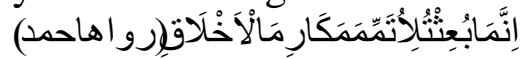

artinya: "sesungguhnya aku diutus untuk menyempurnakan akhlak mulia." (HR. Ahmad)Perhatian Islam yang demikian terhadap pembinaan akhlak ini dapat pula dilihat dari perhatian Islam terhadap pembinaan jiwa yang harus didahulukan dari pada pembinaan fisik, karena dari jiwa yang baik inilah akan lahir perbuatan-perbuatan yangbaik yang pada tahap selanjutnya akan mempermudah menghasilkan kebaikan dankebahagiaan pada seluruh kehidupan manusia, lahir dan batin (Nata, 2003, hal. 158).

Dewasa ini pesantren telah banyak diminati oleh masyarakat luas, meskipun sempat hanya dipandang sebelah mata disepuluh tahun kebelakang, namun belakangan ini pesantren telah banyak dilirik oleh masyarakat luas. Secara umum, pesantren diartikan sebagai tempat tinggal parasantri.Oleh karena itu perkataan pesantren disinyalir berasaldarikata santri juga, dengan penambahan awalan "pe" dan akhiran "n".Secara terminologis, pesantren didefinisikan sebagai lembaga pendidikan tradisionalIslam untuk mempelajari, memahami, mendalami, mengahayati, dan mengamalkan ajaran Islam dengan menekankan pentingnya moral keagamaan sebagai pedoman prilaku sehari-hari(Damopoli, 2011, hal. 58).

Tafsir(2010, hal. 192) mengatakan bahwa pesantren merupakan lembaga pendidikan Islam yang tertua di Indonesia, setelah rumah tangga.Sekalipun demikian, perhatian para peneliti terhadap pesantren belum begitu lama dimulai.Hasil-hasil penelitian itu sudah diedarkan berupa makalah, buku dan majalah.Banyak juga jumlahnya namun masih banyak "rahasia" pesantren yang belum diungkapkan oleh para peneliti.Sebagian dari yang belum diungkapkan itu adalah bagian-bagian yang memang amat sulit diungkapkan. Pesantren sebagai komunitas dan sebagai lembaga pendidikan yang besar jumlahnya dan luas penyebarannya di berbagai pelosok tanah air telah banyak memberikan saham dalam pembentukan manusia Indonesia yang religius. Lembaga pesantren telah melahirkan banyak pemimpin bangsa di masa lalu, kini dan agaknya juga di masa yang akan datang.

Pendidikan di pondok pesantren dijadikan bukti pendukung masyarakat yang cukup kuat, yang mampu menggerakan gairah kependidikan. Menurut Noor (2006, hal. 130) dalam sistem pendidikan nasional disebutkan di antara tujuan pendidikan ialah menciptakan manusia Indonesia yang memiliki kepribadian mantap dan mandiri serta rasa tanggung jawab kemasyarakatan dan kebangsaan. Oleh sebab itu, pendidikan yang diselenggarakan pondok pesantren dikembangkan tidak hanya berdasarkan pada pendidikan keagamaan semata, melainkan dalam pondok pesantren tersebut diarahkan pembinaan mental dan sikap santri untuk hidup mandiri, meningkatkan keterampilan dan berjiwa entrepreneurship. Mengingat lembaga 
pendidikan pondok pesantren sebagai lembaga pendidikan tertua di negeri ini, maka tidaklah heran ketika banyak para pemimpin, penguasa, elit politik, serta banyak lagi orang-orang pintar yang sangat dibutuhkan oleh masyarakat, mereka adalah hasil pendidikan dan pengajaran pondok pesantren. Manfaat lain yang banyak dirasakan oleh masyarakat, melalui pendidikan dan pengajaran di pondok pesantren tidak diperlukan biaya mahal, sehingga dapatdijangkau oleh masyarakat ekonomi lemah sekali pun, terutama di daerah pedesaan. Namun demikian, tidak berarti pendidikan yang murah tidak menghasilkan kualitas, bahkan sebaliknya.

Kehadiranpesantrendapatdisebutseba gaiagenperubahansosial, yang selalumelakukankerja-

kerjapembebasanpadamasyarakatdarisega lakeburukan moral, penindasanpolitik, kemiskinanilmupengetahuan, danbahkank emiskinanekonomi(Aly, 2011, hal. 158).Selainitusalahsatumisididirikannyap esantrenadalahmenyebarluaskaninformasi ajarantentanguniversalitasIslamkeseluruh Pelosok Negara Indonesia yang berwatakpluralis, baikdalamdimensikepercayaan,

budayamaupunkondisisosialmasyarakat. Melalui media yang dikembangkanparawalidalambentukpesan tren, ajaranIslamlebihcepatmembumi di Indonesia.

Selainfaktorkebutuhanmasyarakat

Indonesia, bolehjadiadafaktor lain yang mempercepat proses

pembumianpesantren di Indonesia danbertahan lama hinggasekarangini, misalnyafaktorkarakteristikdantipenya yang unikdantipikal.

Pesantren sebagai lembaga agama Islam menjadikan kebersihan itu sebagai komponen utama dalam setiap kegiatan.Akan tetapi, melihat fenomena yang terjadi dari dahulu kala sampai sekarang seorang santri atau seseorang siswa yang mondok di Pesantren banyak yang memiliki penyakit Kulit, bahkan fenomena seperti ini tidak hanya terjadi dalam satu Pesantren saja melainkan di banyak Pesantren.Selain dari ayat Alqurān diatas, menurut Undang-Undang no 36 tahun 2009 pasal 9 menjelaskan bahwa, "Setiap orang berkewajiban ikut mewujudkan, mempertahankan, dan meningkatkan derajat kesehatan masyarakat yang setinggi-tingginya"(UU Sisidiknas, 2013).

Setelah melakukan survey ke beberapa pesantren yang ada di Kota Bandung, peneliti menemukan sebuah masalah yang dialami oleh banyak pesantren yakni, santri yang mukim di pesantren tersebut kebanyakan pernah mengalami penyakit kulit. Pesantren salafiyah atau bisa disebut dengan pesantren tradisional yang mendapatkan rating tertinggi dalam masalah penyakit kulit tersebut.Masalah tersebut timbul karena disiplin kebersihan yang belum diutamakan oleh pesantren salafiyah tersebut.Pesantren Salafiyah yang peneliti maksud ialah Pesantren ini memiliki fasilitas seperti masjid, asrama, Kiai(Aly, 2011, hal. 182).

Pesantren Al-Basyariyah sebagai lembaga pendidikan formal memiliki peranan sentral di lingkungan masyarakat.Pesantren Al-Basyariyah memiliki visi yakni Terciptanya pemimpin muttaqīn, mutafaqqih fiddīn, berbudi luhur, ikhlas beramal, berwawasan luas, berbadan sehat, terampil, dan berjiwa juang. Menjadi lembur ilmu, majelis disiplin, kancah ibadah, wahana perjuangan untuk mencapai fiddunya $\bar{a}$ hasanah wa fil äkhirati hasanah.Serta misi "Mengajarkan ilmu-ilmu pengetahuan agama Islam dan pengetahuan umum secara seimbang dalam rangka terciptanya kader-kader ulama intelek dan khoirunnās Melatih santri menjadi pengamal ilmu, ahli ibadah, taqorrub dan taat kepada Alláh SWT, Rosulullah dan 
Ulil AmriMendidik santri berakhlak karimah,tawadu, disiplin dalam segala bidang dan berkepribadian Indonesia yang beriman dan bertaqwa" visi dan misi ini dibangun dalam rangka membangun manusia yang beriman dan bertaqwa".

Tapi, nyatanya beberapa masalah ditemukan di dalam Pondok Pesantren Al-Basyariyah tersebut, malasah kebersihan yang menjadi permasalahan sangat besar di Pondok Pesantren AlBasyariyah, para santri yang kurang dalam pemahaman disiplin kebersihan, serta masih adanya santri yang menderita penyakit kulit.Melihat permaslahan diatas maka perlu bagi peneliti untuk melaksanakan penelitian di Pondok Pesantren Al-Basyariyah tersebut. Sehingga dengan ini peneliti mengambil judul peneliitain yang diberi judul “ Model Pembinaan Akhlak Mulia dalam Meningkatkan dan Menjaga Disiplin Kebersihan di Pondok Pesantren AlBasyariyah Bandung".

\section{METODE}

Metode penelitian yang digunakan adalah metode deskriptif.Metode ini digunakan untuk menggambarkan suatu gejala, peristiwa, dan kejadian yang terjadi pada masa sekarang. Sukmadinata ( 2012, hal. 75) mengatakan bahwa Penelitian deskriptif banyak dilakukan dalam ilmu sosial khususnya ilmu perilaku.Menurut Sukmadinata (2009, hal. 72) metode deskriptif ditujukan untuk mendeskripsikan atau menggambarkan fenomena-fenomena yang ada, baik fenomena yang bersifat alamiah ataupun rekayasa manusia. Penelitian ini mengkaji bentuk, aktivitas, karakteristik, perubahan, hubungan, kesamaan, dan perbedaannya dengan fenomena lain. Dalam penelitian ini, peneliti mencari model pembinaan akhlak mulia dalam meningkatkan dan menjaga disiplin kebersihan di Pondok Pesantren Al-Basyariyah Bandung.Peneliti yang bertindak sebagai instrumen penelitian, mulai mengumpulkan, mendeskripsikan, dan menganalisi data yang telah diperoleh selama penelitian.Satori dan Komariah (2011, hal. 25) mengatakan bahwa Penelitian kualitatif adalah suatu pendekatan penelitian yangmengungkap situasi sosial tertentu dengan mendeskrifsikan kenyataan secara benar, dibentuk oleh kata-kata berdasarkan teknik pengumpulan dan analisis data yang relavan yang diperoleh dari situasi yang alamiah.

Sesuai dengan permasalahan sebelumnya, dalam penelitian ini secara fokus meneliti model pembinaan akhlak Mulia dalam meningkatkan dan menjaga disiplin kebersihan yang dilaksanakan di salah satu pondok Pesantren Bandung yaitu Pondok Pesantren AlBasyariyah.Peneliti menggunakan variasi analisis kegiatan.Peneliti menganalisis secara cermat, suatu aktivitas, proses, peristiwa, yang ada di lembaga pendidikan Pondok Pesantren AlBasyariyah Bandung.

Partisipan atau yang menjadi subjek penelitian ialah, Pimpinan Pondok putra, Pimpinan pondok Putri, Penanggung jawab Kebersihan Putra, Penanggung jawab kebersihan Putri dan Bagian KKPL dan PHMP, dengan rincian sebagai berikut:

1. Pimpinan Pondok Putra, Ustaz Endang Suhendi.

2. Pimpinan Pondok Putri, Ustazah Ina Siti Nurhasanah,.

3. Penanggung Jawab Kebersihan Santri putra, Ustaz Cepi Rizky Supardi.

4. Penanggung Jawab Kebersihan Santri Putri, Ustazah Aberty Primaria Dacosta.

5. Ketua Bagian KKPL dan PHMP Putri, Nurhasanah

6. Ketua Bagian KKPL dan PHMP Putra, Yazid al-Bustomi

Alasan peneliti memilih subjeksubjek diatas, dikarenakan mereka semua 
ialah orang-orang yang mengetahui mengenai Objek penelitian yang akan diteliti oleh peneliti. Peneliti tidak mewawancara Pimpinan Umum Pondok, yaitu Buya Drs. KH.Saeful Azhar dikarenakan kondisi beliau yang kurang sehat, serta atas saran dari Hj. Ummi Sajaah selaku Pendamping Buya.

Penelitian dilaksanakan di Pondok Pesantren Al-Basyariyah Bandung. Pondok Pesantren Al-Basyariyah Bandung merupakan salah satu Pesantren yang berada di Kecamatan Margaasih Kabupaten Bandung serta memiliki ikatan dengan Pondok Pesantren Gontor Ponorogo, karena para pendiri Pondok Pesantren Al-Basyariyah merupakan alumni dari Pondok Pesantren Gontor Ponorogo Jawa Timur. Pondok Pesantren Al-Basyariyah disebut dengan Pesantren modern karena dalam sistem pendidikan yang diterapkannya memadukan antarakurikulum Pondok Pesantren dan kurikulum Departemen Agama. Alumni atau lulusan dari Pondok Pesantren AlBasyariyah Bandung bisa melanjutkan ke Perguruan Tinggi Negeri atau swasta, karena mendapatkan izazah resmi dari negara yang stara dengan Sekolah Menengah Atas (SMA) atau Madrasah Aliyah (MA) umum.Metode pengumpulan data merupakan cara atau langkah yang ditempuh dalam mengumpulkan data yang dibutuhkan untuk menjawab masalah penelitian. Metode pengumpulan data yang digunakan dalam penelitian ini adalah dengan beberapa cara, yaitu: 1 . Observasi Menurut Sutrisno hadi (Suwandi, 2008)mengemukakan bahwa observasi merupakan suatu proses yang kompleks, suatu proses yang tersusun dari berbagai proses biologis dan psikologis. Dua diantara yang terpenting adalah prosesproses pengamatan dan ingatan.Pada pengamatan ini tahapan yang dilakukan meliputi, pengamatan secara umum mengenai hal-hal yang sekiranya ada kaitannya dengan fokus penelitian.Dalam penelitian ini, peneliti melakukan observasi dengan melihat dan mengamati kegiatan siswa atau santri ketika di Asrama, Lapangan, Kantin, aula dan tempat lainnya yang ada di lingkungan Pondok Pesantren Al-Basyariyah Bandung.2. Wawancara Esterberg(Sugiyono, 2010, hal. 317) menjelaskan bahwa wawancara adalah pertemuan dua orang untuk bertukar informasi dan ide melalui tanya jawab, sehingga dapat di konstruksikan makna dalam topik tertentu. Menurut Sugiyono (2010, hal. 194) wawancara digunakan sebagai teknik pengumpulan data apabila peneliti ingin mengetahui hal-hal dari respondennya. Dalam wawancara ini, peneliti menggunakan wawancara terstruktur dan semiterstruktur, untuk itu peneliti membuat seperangkat pertanyaan-pertanyaan wawancara, kemudian menggali informasi dan data yang lainnya dengan menggunakan pedoman wawancara.Peneliti mewawancarai Ustaż, Ustāżāh, Penanggung jawabkebersihan Putra dan Putri serta bagian KKPL dan PHMP (Bagian Kebersihan Ketertiban Pemeliharaan Lingkungan dan Pemelihara Harta Milik Pondok).3. Studi dokumentasi merupakan suatu teknik pengumpulan data dengan menghimpun dan menganalisis dokumen-dokumen, baik dokumen tertulis maupun dokumen elektronik. Yang dimaksud dokumen dalam penelitian ini seperti dokumen Profil Pondok Pesantren, Struktur kepengurusan Pesantren, peraturanperaturan kebersihan santri, jadwalkegiatan, data santri, dan lain sebagainya. Setelah melakukan semua pengumpulan data, maka di lanjutkan dengan menganalisis data temuan dan mereduksi data.Untuk mencapai derajat kepercayaan dalam penelitian ini, peneliti melakukan beberapa uji validitas data, validitas dalam penelitian ini dengan melakukan: Kecukupan pengamatan, dalam penelitian ini pengamatan 
dilakukan oleh peneliti hampir pada setiap moment kegiatan santri yang terjadi dalam kompleks Pondok Pesantren. Di asrama, Kamar mandi, jemuran, lapangan terbuka, kantin. Demikian juga, pada pagi hari, siang hari, sore hari dan malam hari. Hal ini dilakukan untuk mencapai keabsahan data dan menangkap makna dari peristiwa yang terjadi.Trianggulasi, menurut Wiliam Wiersma (Sugiyono, 2010, hal. 372) triangulasi dalam pengujian kredibilitas ini diartikan sebagai pengecekan data dari berbagai sumber dengan berbagai cara, dan berbagai waktu. Member-chek, dilakukan untuk mengkonfirmasi seluruh data yang diperoleh.

\section{HASIL DAN PEMBAHASAN}

Pondok pesantren adalah lembaga pendidikan yang tumbuh dan berkembang dalam adat, Budaya serta tradisi bangsa Indonesia, wajah dan karakter keagamaan serta budaya Islam indonesia bahkan budayanya sendiri secara keseluruhan banyak dibentuk oleh pesantren, sehingga pada masa penjajahan pondok pesantren merupakan kubu pertahanan yang memiliki peranan penting bagi perjuangan bangsa, dan hingga saat ini eksistensi pondok pesantren masih terus dipertahankan bahkan dikembangkan agar dapat meningkatkan peranannya dalam usaha menciptakan manusia seutuhnya, pesantren dalam masyarakat Indonesia merupakan sel sel hidup atau unit dinamik yang tersebar di kampung kampung, desa desa, dan perkotaan yang secara garis besarnya menyatu dalam sebuah jaringan yang berfungsi mengIslamkan masyarakat, dalam arti yang luas mencakup pembimbingan dan pemeliharaan. Indikasi tumbuhnya lembaga pendidikan yang berinspirasi pada lembaga pendidikan di timur tengah belum pasti diketahui kapan terbentuknya, akan tetapi produk-produk hasil pengemblengan lembaga ini telah merambah ke berbagai sektor kehidupan dan ikut serta dalam pembangunan dan pengembangan bangsa Indonesia (D.1).

Kiai dalam sebuah pesantren dipandang sebagai senter penerang dari eksistensi lembaga tersebut. Maju mundur, besar kecilnya pondok tertumpu pada sistem pengelolaan / manajemen seorang Kiai, pengembangannya sejalan dengan berkembangnya tingkat karismatik Kiai sebagai tokoh agama dan masyarakat, biasanya salah seorang Kiai pejuang yang mampu melihat tanda tanda zaman dan mampu menjawab tantangan tantangan besar yang dihadapinya, dan dengan demikian beliau mampu mengembangkan pesantrennya sesuai dengan tuntutan zaman. Faktor komunitas penduduk pesantren yang lebih banyak akan lebih sulit pengelolaannya dibanding yang lebih sedikit, hal ini adalah gambaran terhadap tuntutan efektifitas manajemen seorang Kiai, sehingga kemajuan pesantren tetap berkesinambungan dari pihak pendiri sampai kepada pihak pihak yang dipercaya untuk lebih mengembangkan pondok pesantren dengan manajemennya tersebut, agar tidak terjadi kematian pesantren bersamaan dengan kematian seorang Kiai (D.1).

Disaat kebutuhan terhadap lembaga pembinaan akhlak, ilmu dan sumber daya manusia yang konsekuen dan dapat dipercaya sulit didapat maka pandangan pun akan menyudut pada model pesantren, Al-Basyariyah sebagai model pesantren yang beracuan terhadap hal hal yang terpaparkan diatas mampu memberikan kontribusi yang lebih untuk pembinaan segala aspek yang dibutuhkan dalam mengarungi bahtera kehidupan selanjutnya, dengan pola pendidikan dan metoda pengelolaan pondok yang sangat disiplin (D.1).

Pembinaan adalah kegiatan untuk memelihara agar sumber daya manusia dalam organisasi taat asas dan konsisten 
melakukan rangkaian kegiatan sesuai dengan rencana yang telah ditetapkan (Sudjana, 2008, hal. 9). Pola pembinaan yang dilaksanakan di Pondok pesantren Al-Basyariyah dilaksanakan selama 24 jam dalam sehari, pembinaan dimulai dari pukul 04.00 dengan kegiatan șalat tahajud bersama. șalat tahajud ini hanya di wajibkan bagi kelas 5 TMI dan 6 TMI baik itu santri putra maupun santri putri. Kegiatan ini dilaksanakan untuk membina atau melatih para santri agar terbiasa bangun pada pagi hari serta menjaga kesehatan bagi para santri karena menurut Buya dalam Irsyadat atau Pidato mengatakan bahwa seseorang yang terbiasa bangun di sepertiga malam maka ia akan sehat(OA.1).

Pembinaan akhlak yang di laksanakan di Pondok Pesantren AlBasyariyah, banyak macamnya yakni pembinaan akhlak sosial, akhlak kebersihan dan lain sebagainya. Akhlak kebersihan di Pondok Pesantren AlBasyariyah sangatlah menjadi perhatian khusus, dikarenakan Pondok pesantren AlBasyariyah sangat memegang teguh katakata النظافة من الايمان yang memiliki arti "kebersihan dari pada Iman". Pembinaan akhlak merupakan tumpuan perhatian utama dalam Islam. Hal ini dapat dilihat dari salah satu misi kerasūlan nabi Muhammad SAW yang utama ialah untuk menyemurnakan akhlak yang mulia. Dalam salah satu Hadis nya beliau menegasakan:

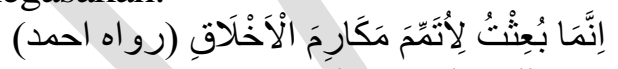

Artinya: "sesungguhnya aku diutus untuk menyempurnakan akhlak mulia." (HR. Ahmad) (Nata A, 2003, hal. 158).

Perhatian Islam yang demikian terhadap pembinaan akhlak ini dapat pula dilihat dari perhatian Islam terhadap pembinaan jiwa yang harus didahulukan dari pada pembinaan fisik, karena dari jiwa yang baik inilah akan lahir perbuatan-perbuatan yang baik yang pada tahap selanjutnya akan mempermudah menghasilkan kebaikan dan kebahagiaan pada seluruh kehidupan manusia, lahir dan batin (Nata, 2003, hal. 158).

Menurut Hasan (2008, hal. 201) mengemukakan bahwa tujuan konsep kebersihan dalam Islam adalah untuk menghasilkan masyarakat yang sehat dan memiliki kekebalan terhadap penyakit, dan individu yang sehat (jiwa dan raga) yang mampu untuk menerapkan dan menyebarkan pesanpesan Alláh ke seluruh dunia. Ajaran kebersihan, dalam Islam, meliputi hal yang sangat luas.Kebersihan dalam Islam, meliputi kebersihan jiwa dan kebersihan fisik.Hal ini menunjukan bahwa Islam sangatlah menjaga keseimbangan antara jiwa dan fisik. Kebersihan adalah perilaku sehat yang penting dalam gaya hidup umat Islam.

Banyak hal yang dilakukan untuk selalu menjaga dan meningkatkan disiplin kebersihan yakni pembiasaan, penanaman dan pengamalan (WU.1). Sebagaimana yang dijelaskan oleh Ahmad Marimba mengungkapkan bahwa Pembinaan merupakan suatu proses, proses merupakan jalan yang panjang dan banyak taraf-taraf yang harus dilalui yaitu sebagai berikut : Pembiasaan, Pembentukan pribadi, sikap dan mental, Pembentuk kerohanian yang luhur. Dengan demikian yang timbul adalah pemikiran serta perbuatan yang didasari oleh keinsyafannya sendiri dengan penuh rasa tanggung jawab sehingga mereka akan mengamalkan ajaran Islam dengan kesadaran diri sendiri (Shofiya, 2008, hal. 15).

Untuk melaksanakan proses-proses pembiasaan tersebut maka, Pondok Pesantren Al-Basyariyah membuat tata tertib atau peraturan-peraturan mengenai disiplin kebersihan, Menurut Jamess Drever disiplin adalah kemampuan mengendalikan perilaku yang berasal dari dalam diri seseorang sesuai dengan halhal yang telah di atur dari luar atau norma yang sudah ada(Masbid, dkk, 2014). 
Selain itu di Pondok pesantren AlBasyariyah terdapat personal-personal khusus untuk menjaga dan meningkatkan kebersihan tersebut yakni, adanya Penanggung jawab Kebersihan, baik itu di santri putra maupun di santri putri adapun Penanggung jawab kebersihan pada santri putra yakni, Ustāà Cepi Rizky Supardi dan penanggung jawab kebersihan pada santri Putri yakni, Ustäzah Aberty Primaria Dacosta. Selain penanggung jawab terdapat pula Bagian KKPL dan PHMP dari OSPA (Organisasi Santri Pesantren Al-Basyariyah) (D.2).

Perencanaan untuk membuat peraturan yang dibuat oleh Bagian KKPL dan PHMP, Banyak hal yang harus dilalui dalam Pembuatan tata tertib kebersihan, tata tertib kebersihan berawal dari keluhan-keluhan santri yang dilontarkan kepada DPS (Dewan Perwakilan Santri), yang mana setiap DPS yang telah dibentuk oleh Ketua OSPA akan melaporkan keluhan-keluhan santri tersebut. Keluhan-keluhan santri yang bersangkutan dengn Kebersihan maka akan di berikan kepada bagian KKPL dan PHMP, kemudian oleh Bagian KKPL dan PHMP keluhan-keluhan tersebut diolah menjadi program kerja serta peraturanperaturan . peraturan yang telah dibuat akan dimusyawarahkan dalam Musyawarah Kerja yang dihadiri oleh semua pengurus OSPA. Setelah kesepakan diambil maka terbentuklah Program Kerja dan Peraturan-Peraturan tentang Disiplin Kebersihan Pondok Pesantren Al-Basyariyah (WBK.1).

Sebagaimana yang dikatakan oleh Kaufman(Harjanto, 2010, hal. 2) bahwasannya perencanaan merupakan suatu proyeksi tentang apa yang diperlukan dalam rangka mencapai tujuan absah dan bernilai. Perencanaan ini di buat dengan sedemikian rupa salah satunya dengan adanya peraturanperauran yang di buat oleh pengasuh dan pengurus pondok.
Teknik disiplin seperti ini disebut dengan Teknik Cooperatif Control, Teknik ini antara pendidik atau Pembina dan peserta didik atau dalam penelitian ini disebut dengan Santri yang dibina harus saling bekerja sama dalam menegakan disiplin. Dalam hal ini pendidik dan peserta didik membuat bersama-sama suatu kesepakan bersama dalam menegakan disiplin ( Imron, 2012, hal. 175).Pelaksananaan disiplin kebersihan di Pondok pesantren AlBasyariyah memiliki dua sistem. Sistem yang terprogram dan sistem yang tidak terprogram, misalnya sistem yang terprogram pelaksanaan Tanziff sesuai dengan jadwal Tanzîf yakni pagi dan sore hari.Sedangkan pelaksanaan Tanzîf yang tidak terprogram yakni pada waktu-waktu yang tidak bisa ditentukan (WU.1).

Setiap pelaksanaan pembagian Tanzîf atau bersih-bersih di Pondok Pesantren Al-Basyariyah para santri berkumpul di Lapangan dengan tertib sesuai dengan kelas masing-masing.para santri mendengarkan dengan seksama ketika dibagikan tempat untuk bersih-bersih. Setelah mereka mendapatkan tugas nya masing-masing mereka bergegas menuju gudang penyimpanan alat bersih-bersih untuk meminjam alat-alat tersebut (OL.1).

Adapun menurut Ustāż. Endang Banyak system yang dijalankan di Pondok Pesantren Al-Basyariyah ini, system yang digunakan tergantung pada tempat atau bagian wilayah tertentu dimana system tersebut dijalankan, contohnya di kelas, di kelas memiliki system dalam menjalankan dan menjaga kebersihan di dalam kelas, dengan menmbuat jadwal Tanzîf serta penanggung jawab di setiap kelas. Di hujrāh pun sama seperti itu, memiliki system kebersihan tersendiri. Akan tetapi, seluruh sistem kebersihan pada masingmasing wilayah tersebut di di bawahi oleh pengurus OSPA yakni Bag.KKPL dan PHMP (Bagian Kebersihan 
Ketertiban Pemeliharaan Lingkungan dan Pemelihara Harta

Milik Pondok).Bag.KKPL dan PHMP memiliki tata tertib khusus kebersihan bagi para santri, setiap pelanggaran-pelanggaran yang di lakukan santri maka Bag. KKPL dan PHMP akan menghukum sesuai dengan peraturan-peraturan kebersihan yang telah di sahkan (WU.2).

Di pondok Pesantren Al-Basyariyah ini, pelaksanaan Tanzîf memiliki TPL (Tim Peduli Lingkungan) dan TK (Tim Khusus), TPL memiliki tugas membersihkan ketika tidak ada jadwal untuk Tanẓif , sedangkan TK memiliki tugas yakni membersihkan seluruh lantai yang ada di Rayon Putra. Keunikan Santri Putra Pondok pesantren AlBasyariyah, mereka semua sangat antusias sekali ketika di beri tugas untuk membersihkan Pondok, karena hasil kerja mereka selalu di hargai Oleh Pimpinan Pondok.Ucapan Terima Kasih yang di lontarkan Oleh Pimpinan Pondok yakni Buya sangatlah memotivasi santri Putra untuk selalu rajin dalam menjaga kebersihan (WU.1).

Pelaksanaan bersih-bersih atau biasa disebut Tanzīf dilaksanakan 5 kali dalam sehari, yakni pada jam setelah șalat shubuh, jam 07:30, jam 09:30, Setelah șalat zuhur, Setelah șalat Asar. Dalam pelaksanaan keseharian santri yang Tanzîf dibagikan perkelas, setiap kelas diberikan jadwal masing-masing dalam membersihkan lingkungan Pondok. Bag KKPL dan PHMP akan memanggil satu Kelas pada setiap harinya dan membagikannya tugas membersihkan pada masing-masing santri. Setelah pembagian selesai maka bag KKPL dan PHMP akan mengontrol seluruh lingkunagn pondok yang sedang dibersihkan, jika ada santri yang tidak benar dalam membersihkan pondok maka ia akan menegur secara langsung dan memberikan contoh cara yang benar dalam membersihkan tempat tersebut (W BK.1).
Dalam pelaksanaan Tanzîf atau bersih-bersih sebagai penanggung jawab kebersihan, ikut serta dalam pengawasaan terhadap cara santri Tanzî̄f, meskipun tidak pada setiap harinya, penanggung jawab kebersihan terjun secara langsung ketika pelaksanaan Tanzîf secara besarbesaran atau biasa disebut dengan Tanzîf akbar, yang biasanya dilaksanakan pada setiap hari jumat dan ketika ada acaraacara tertentu yang memang mengharuskan penanggung jawab turun langsung dalam pelaksanaan kebersihan. Karena jika tidak dipantau langsung maka santri akan leha-leha dalam membersihakan atau Tanzîf pondok (WH.2).

Pelaksanaan Tanzîf atau bersihbersih di Pondok Pesantren AlBasyariyah dilaksakan setiap hari secara terus menerus, hal tersebut untuk membuat satri tersbiasa dengan menjaga dan meningkatkan kerebsihan. Sebagaimana yang dikatakan oleh Ahmad Marimba(Shofiya, 2008) dalam proses pembinaan Pada taraf kedua ini, perlu diberi pengetahuan dan pengertian serta ditanamkan dasar-dasar keimanan kepada Alláh beserta sifat-sifatnya yang bermanfaat bagi setiap individu. Perlu diingat bahwa dalam menanamkan pengertian, minat dan sikap terhadap siapa yang dibina adalah manusia yang merupakan keseluruhan.Dengan menggunakan pikiran dapatlah ditanamkan pengertian-pengertian dan dengan adanya pengertian maka akan terbentuklah sikap atau pendirian dan pandangan-pandangan mengenai hal tersebut. Selanjutnya, dengan adanya rasa sebagai hamba Tuhan disertai dengan pengertian-pengertian, maka minat dapat diperbesar dan ikut serta dalam pembentukan ini(Shofiya, 2008).

Selain jadwal Tanzīf pada setiap harinya, di Pondok pesantren AlBasyariyah di bentuk tim-tim yang peduli Lingkungan.Di adakannya TPL (Tim Peduli Lingkungan), mereka adalah 
sekelompok santri yang peduli terhadap Lingkungan, yang diberikan tugas untuk selalu menjaga kebersihan di lingkungan pesantren Al-Basyariyah. Tim TPL pertama kali dibentuk pada tanggal 10 september 2012 yang dipilih dari kelas 5 TMI sederajat atau kelas 2 Aliyah. Pada setiap tahunnya Keanggotaan Tim TPL selalu berubah-ubah. Pada tahun berikutnya Tim TPL diambil dari kelas 2 TMI atau 2 Tsanawiyah yang memiliki keinginan untuk menjaga kebersihan Pondok Pesantren Al-Basyariyah, untuk menjadi TPL bag KKPL dan PHMP melaksanakan audisi terlebih dahulu. Audisi yang dilaksanakan dengan cara memberikan perintah kepada setiap calon anggota TPL untuk membersihkan lingkungan Pondok yang cukup sulit dibersihkan oleh santri pada umumnya. Audisi dilaksanakan untuk melihat kinerja para calon anggota TPL, apakah memiliki kredibilitas yang baik atau tidak.

Selain dibentuk tim TPL (Tim Peduli Lingkungan) ada pula TPHK (Tim Peduli Kebersihan Hamām), yang terdiri dari kelas 6 TMI sederajat atau kelas 3 Aliyah. TPHK ini dibentuk untuk selalu menjaga kebersihan kamar mandi saja.Berbeda hanya dengan TPL yang menjaga seluruh kebersihan di Lingkungan Pondok Pesantren AlBasyariyah (WH.2).

Pelaksanaan kegiatan ini dilaksanakan dengan konsisten atau terus menerus, sebagaimana yang telah dikatakan oleh Djuju Sudjana fungsi pembinaan bertujuan untuk memelihara dan menjamin bahwa pelaksanaan program dilakukan secara konsisten sebagaimana yang telah direncanakan (Sudjana , 2008, hal. 9). Selain melaksanakan disiplin kebersihan yang sering pada setiap harinya, di Pondok pesantren Al-Basyariyah terdapat tim-tim khusus untuk melaksanakan kebersihan, adapun tim tersebut ialah: a. TPL (Tim Peduli Lingkungan), mereka adalah sekelompok santri yang peduli terhadap Lingkungan, yang diberikan tugas untuk selalu menjaga kebersihan di lingkungan pesantren Al-Basyariyah. Tim TPL pertama kali dibentuk pada tanggal 10 september 2012 yang dipilih dari kelas 5 TMI sederajat atau kelas 2 Aliyah. Pada setiap tahunnya Keanggotaan Tim TPL selalu berubah-ubah. Pada tahun berikutnya Tim TPL diambil dari kelas 2 TMI atau 2 Tsanawiyah yang memiliki keinginan untuk menjaga kebersihan Pondok Pesantren Al-Basyariyah, untuk menjadi TPL bag KKPL dan PHMP melaksanakan audisi terlebih dahulu. Audisi yang dilaksanakan dengan cara memberikan perintah kepada setiap calon anggota TPL untuk membersihkan lingkungan Pondok yang cukup sulit dibersihkan oleh santri pada umumnya. Audisi dilaksanakan untuk melihat kinerja para calon anggota TPL, apakah memiliki kredibilitas yang baik atau tidak.

b. TPHK (Tim Peduli Kebersihan Hamām), yang terdiri dari kelas 6 TMI sederajat atau kelas 3 Aliyah. TPHK ini dibentuk untuk selalu menjaga kebersihan kamar mandi saja. Berbeda hanya dengan TPL yang menjaga seluruh kebersihan di Lingkungan Pondok Pesantren AlBasyariyah (WH.2).

Agar pelaksanaan pembinaan ini bisa terkontrol, maka selain bagian KKPL dan PHMP, penanggung jawab dan MP3 selalu melaksanakan pengawasan terhadap pelaksanaan disiplin kebersihan, dengan cara mengontro langsung maupun tidak langsung (WH.2). sebagaimana yang dikatakan oleh Djuju Sudjana bahwa pengawasan sangatlah penting untuk meninjau sejauh mana terlaksananya suatu kegiatan, untuk 
mencapai tujuan yang telah ditetapkan (Sudjana, 2008, hal. 201).

Selain melaksanakan pembiasaan mengenai disiplin kebersihan, tidak luput bagi para Pembina untuk selalu memberikan peringatan kepada para santri untuk selalu menjaga dan meningkatkan kebersihan di Pondok Pesantren Al-Basyariyah dengan cara melaksanakan irsyadat atau pidato setelah șalat isya, pidato tersebut berisi banyak hal mulai dari akhlak, kebersihan dan lain sebagainya (WU.1). sebagaimana yang dijelaskan mengenai proses pembinaan yang kedua yakni memberikan pengetahuan agar para santri atau peserta didik dapat memahami dengan pembinaan yang dilaksanakan (Sudjana, 2008).

Untuk menjalankan pembinaan, banyak komponen-komponen yang harus disediakan salah satunya dengan pengadaan sarana prasarana yang mendukung keterlakasanaan disiplin kebersihan di Pondok Pesantren AlBasyariyah ini. (WU.1).Selain sarana dan pra sarana yang di lengkapi oleh Pondok Pesantren Al-Basyariyah, untuk menjalankan disiplin santri khususnya dalam hal kebersihan, maka Pondok pesantren Al-Basyariyah membuat berbagai aturan-aturan mengenai disiplin kebersihan.Peraturan-peraturan tersebut dilengkapi dengan adanya para pengasuh yang ikut bertanggung jawab dalam menjalankan disiplin kebersihan (WBK.1).

Sebagaimana yang dikatakan oleh Sudjana (2010, hal. 202) Komponenkomponen itu meliputi sumber-sumber yang tersedia, sasaran (target group), proses, hasil, dan pengaruh program yang sedang dilaksanakan.

Dalam menjalankan disiplin kebersihan ini yang menjadi sasaran yakni para santri yang berada di Pondok Pesantren Al-Basyariyah Bandung, mereka semua diwajibkan untuk menjalankan serangkaian proses pembinaan disiplin kebersihan, agar mereka dapat menjadi pribadi yang baik. Adanya pelaksanaan pembinaan disiplin kebersihan setiap harinya menandakan adanya sebuah proses pembinaan yang dijalankan. Pelaksanaan disiplin kebershan sangatlah berpengaruh dalam kehidupan para santri Pondok Pesantren Al-Basyariyah, hal ini dapat dilihat dari jumlah santri yang menderita penyakit kulit (Dermatitis) menurun setiap tahunnya (OL.1 dan D.3).

Dalam menjalankan pembinaan selalu ada hambatan dan halangan dalam menjaninya, adapun hambatan dan halangan yang dirasakan oleh pengurus dalam menjalankan pembinaan ialah, Kesulitan atau Hambatan dalam menjalankan disiplin kebersihan di Pondok Pesantren Al-Basyariyah ini ialah menggerakan para penggerak, para penggerak yang di maksud disini ialah jika di kelas ketua kelas, jika di hujrāh ketuahujrāh dan jika di Lingkungan Pondok maka bagian Kebersihan itu sendiri. tetapi, hambatan tersebut membuat Majelis Pimpinan tidak bosan untuk selalu menegur dan mengingatkan para penggeraktersebut, karena Ustāż tau pada usia tersebut, manusia harus selalu di ingatkan dan di tegur jika mereka salah. Maka selaku Majelis Pimpinan Khusunya di Putra, Ustāż tidak bosan untuk selalu Mengingatkan terhadap halhal yang baik (WU.2).

Kesulitan dalam menjalankan disiplin kebersihan di Pondok Pesantren Al-Basyariyah ini ialah, kurangnya kesadaran mengenai disiplin kebersihan dalam jiwa santri, sehingga membuat para santri tidak peduli dengan kebersihan lingkungan (WH.2). Tujuan dari pembinaan akhlak dalam menjaga dan meningkatkan disiplin Al-Basyariyah ialah sesuai dengan Panca Ikrar Santri Pondok Pesantren Al-Basyariyah Butir 3 yang berbunyi, "Kami santriPondokpesantren $\mathrm{Al}$ BasyariyahSiaptempuhmenjadipemimpin 
muttaqīn, muttafaqihfiddīn, berbudiluhur, ikhlasberamal, berpengetahuanluas, berbadansehat, terampil dan berjiwajuang. (D.9).

$$
\text { Proses }
$$

evaluasipembinaandisiplinkebersihan di PondokpesantrenAl-

Basyariyahdilaksnakandengan 2 kali kegiatanevaluasi,

pertamaevaluasidilaksanakansatubulanse kalidenganmengadakanrapatbulananbagis eluruhpengurus yang ada di PondokPesantren Al-Basyariyah. Kedua, dalamacara SARTIJAB (SerahTerimaJabatan) dari OSPA lama kepada OSPA baru (W.BK 1).Tahapevaluasi yang dilaksanakan di PondokPesantren AlBasyariyahsesuaidenganteori yang ada. SebagaimanaHarjanto(2010, hal. 19)mengatakanbahwatahapevaluasi, perluditetapkanmekanismeevaluasitentan gkemajuan yang dicapaisertamendeteksideviasiataupenyi mpangan, proses evaluasidilaksanakansecarabersinambung

Pengawasandilaksanakanolehpenga suhsebagaitindakanuntukmengevaluasiha silpembinaan yang dilaksakan, dalamhalpengawasaninidilaksanakandeng anduacarayaknipengawasansecaralangsun gdanpengawasantidaklangsung.

Pengawasansecaralangsung, yakni para pengasuhterjunlangsungdalampelaksanaa nTanzīfataubersih-bersih

PondokPesantren Al-Basyariyah (WH.2). Sebagaimana yang dikatakanolehSudjanabahwasanyaSubfun gsipengawasanpadaumumnyadilakukante rhadaplembagapenyelenggara program. Subfungsi supervisi dilakukan terhadap pelaksana kegiatan dan subfungsi pemantauan dilakukan terhadap proses pelaksanaan program. Dengan demikian, fungsi pembinaan bertujuan untuk memelihara dan menjamin bahwa pelaksanaan program dilakukan secara konsisten sebagaimana yang telah direncanakan (Sudjana, 2008, hal. 9).

MakaPembinaandisiplinkebersihani ni,

berhasildalammenjalankanberbagaikegiat andalampembinaan. Hasilinidapatterlihat dari grafikmenurunnyasantri yang menderitapenyakitdermatitis (Budug) padasetiaptahunnya.Dapatdilihatpadagraf ik yang tercantum di data hasilpenelitianbagianevaluasiPembinaan DisiplinKebersihan di PondokPesantren Al-Basyariyah. Padasetiapbulannyasantri yang

menderitapenyakitDermatitissemakinmen urun, menurutBagianKebersihan yang menjaga dan mengelola POSKESTREN (Pos KesehatanPesantren) menjelaskanbahwakebanyakansantri yang menderitapenyakitDernatitisialahsantriPu tra (D.3).

Pembinaandisiplinkebersihan di

PondokPesantren

Al-

Basyariyahdikatakanberhasil,

bukanhanyaterlihat dari grafikkesehatan yang tersedia di Poskestren, melainkan dari

rasa tanggungjawabsantriterhadapkebersihan. Ketikapenelitimelaksanakanpenelitian, penelitimelihatsalahsatusantriPutri yang memasukansampah yang sembarangandibuangolehsantrilain.denga nsertauntukmeyakinkankejadiantersebut, penelitibertanyakepadaUstäżahAbertyseb agaipenanggungjawabkebersihanmengen aihaltersebut, dan UstāżahAbertymembenarkansikapsantrite rsebut (WH.1).

Hal

tersebutmenunjukanbahwasantritersebut memilikiakhlak yang baik. Sebagaimana Ahmad Saebanimenyebutkanbahwaciri dari akhlakmuliasalahsatunyaPerbuatan yang timbul dari dalamdiri orang yang mengerjakannya, tanpa ada paksaanatautekanan dari luar. Perbuatan akhlak adalah perbuatan yang dilakukan atas dasar kemauan, pilihan, dan 
keputusan yang bersangkutan (2010, hal. 14-15).

\section{KESIMPULAN}

Kesimpulan diambil dari hasil analisis terhadap hasil penelitian berdasarkan rumusan masalah yang dikemukakan pada BAB I. Kesimpulan ini akan mencakup (a) tata tertib dan pelaksanaan kebersihan di Pondok Pesantren Al-Basyariyah, (b) Disiplin komponen dalam memelihara kebersihan (c) Hambatan dan Kesulitan dalam melaksanakan kebersihan (d) Hasil Pembinaan Akhlak dalam menjaga dan meningkatkan disiplin kebersihan di Pondok Pesantren Al-Basyariyah.

Pondok Pesantren Al-Basyariyah ialah pesantren modern yang menerapkan kurikulum Negara dengan pelajaran kepesantrenan.Pondok pesantren AlBasyariyah merupakan pesantren yang sangat menjunjung tinggi kebersihan, baik itu kebersihan personal maupun kebersihan lingkungan.banyak peraturanperaturan yang diterapkan untuk menjaga dan meningkatkan kebersihan di Pondok Pesantren Al-Basyariyah. Peraturanperaturan tersebut ialah peraturan yang dibuat oleh Para pemimpin Pondok dan peraturan yang dibuat oleg organisasi santri Pesantren Al-Basyariyah. Dengan peraturan yangbegitu banyaknya dapat terlihat bahwa pesantren Al-Basyariyah sangat menjungjung tinggi kebersihan Pondok Pesantren Al-Basyariyah.

Perencanaan tidak akan berhasil jika tidak dilaksanakan, pelaksanaan pembinaan disiplin kebersihan di Pondok Pesantren Al-Basyariyah sudah baik, karena sudah sesuai dengan teori pembinaan yang ada. Pelaksanaan disiplin kebersihan, dilaksanaan pada setiap hari dengan cara, pembagiaan tandzif atau bersih-bersih yang dilaksanakan secara bergantian. Dalam pelaksanaan disiplin kebersihan tidak luput dari pengawasan asatidz dan bagian Kebersihan di Pondok Pesantren Al-
Basyariyah.Sehingga pelaksanaan disiplin Kebersihan dapat berjalan dengan lancar.Meskipun tidak setiap hari melaksanakan pengawasan secara langsung, namun pelaksanaan disiplin kebersihan dapat berjalan dengan baik.

Dalam menjalankan atau melaksanakan disiplin kebersihan, banyak komponen yang harus disiapkan oleh pesantren Al-Basyariyah, adapun komponen-komponen yang disiapkan dalam menjalankan disiplin kebersihan,ialah dengan menyediakan sarana dan prasarana yang dibutuhkan oleh santri. Selain sarana dan prasarana yang terpenuhi.Santri juga mendapatkan pelajaran mengenai pentingnya menjalankan disiplin kebersihan dari para Asātiz atau Pembina.Setiap pelaksanaan suatu kegiatan, selalu ada hambatan dan halangan dalam menjalakannya, begitu pun dengan pelaksanaan disiplin kebersihan di Pesantren AlBasyariyah.Hambatan yang dirasakan oleh para Pembina atau asatidz Pesantren Al-Basyariyah ialah sulitnya mengatur para pengurus yang bertanggung jawab dalam memimpin terlaksananya disiplin kebersihan, serta kurangnya rasa peduli dan tanggung jawab terhadap kebersihan lingkungan.

Sistem Evaluasi dari pembinaan Akhlak mengenai disiplin kebersihan di Pondok Pesantren Al-Basyariyah Bandung, dilaksanakan dengan kurang lancar.System evaluasi pembinaan akhlak di Pondok Pesantren Al-Basyariyah ini menggunakan tekhnik non tes, teknik non tes yang digunakan ialah pengamatan atau observasi.Evaluasi pembinaan kebersihan dilaksanakan secara rutin satu tahun sekali oleh anggota OSPA (Organisasi Santri Pesantren AlBasyariyah) dalam bentuk LPJ (Laporan Pertanggung Jawaban) sebagaimana yang dikemukakan oleh Ustāż Endang Suhendi dan ketua Bagian Kebersihan Nurhasanah.Evaluasi tersebut merupakan evaluasi terakhir dalam satu tahun, yang 
mana hasil evaluasi tersebut diserahkan kepada Pimpinan Pondok Pesantren AlBasyariyah.pembinaan akhlak mulia dalam meningkatkan dan menjaga disiplin kebersihan di pesantren AlBasyariyah mendapatkan respon yang baik dari kesehatan santri Pesantren AlBasyariyah. Hal tersebut bisa dilihat dari grafik santri sakit dermatitis yang semakin tahun makin menurun penderitanya.Kesimpulan ini diambil berdasarkan latar belakang masalah dalam penelitian ini yang membicarakan mengenai banyaknya santri yang menderita penyakit Dermatitis (Budug).

\section{REFERENSI}

Aly, A. (2011). Pendidikan Islam Multikultural di Pesantren. Yogyakarta: Pustaka Pelajar.

Azhari, F. (2012). Model Pembinaan Keagamaan Islam pada Pekerja Seks Komersial. Salatiga: Sekolah Tinggi Agama Islam Negeri.

Damopoli, M. (2011). Pesantren Modern IMMIM Pencetak Muslim Modern. Jakarta: Rajawali Pers.

Harjanto. (2010). Perencanaan Pengajaran. Jakarta: Rineka Cipta.

Hasan, P. (2008). Pengantar Psikologi Kesehatan Islami. Jakarta: Rajawali Pers.

Imron, A. (2012). Manajemen Peserta Didik Berbasis Sekolah. Jakarta: Bumi Aksara.

Masbid,dkk. (2014, Juli 16). Dunia Pelajar. Dipetik April 1, 2015, dari Blogspot: http://www.duniapelajar.com/201 4/07/16/pengertian-disiplinmenurut-para-ahli/

Nata, A. (2003). Akhlak Tasawuf. Jakarta: Raja Grafindo Persada.

Noor, M. (2006). Potret Dunia Pesantren. Bandung: Humaniora.
Saebani, B. A. (2010). Ilmu Akhlak. Bandung: Pustaka Setia.

Satori, D., \& Komariah, A. (2011). Metodologi Penelitian Kualitatif. Bandung: Alfabeta.

Shofiya, M. (2008). Pembinaan Keagamaan Pada Anak dalam Keluarga Single Parent.Yogyakarta: Universitas Islam Negeri Sunan Kalijaga.

Sudjana, D. (2008). Evaluasi Program Pendidikan Luar Sekolah. Remaja Rosdakarya.

Sudjana, D. (2010). Manajemen Program Pendidikan. Bandung: Falah.

Sugiyono. (2010). Metode Penelitian Kuantitatif Kualitatif dan $R \& D$. Bandung: Alfabeta.

Sukmadinata, N. S. (2009). Metode Penelitian Pendidikan. Bandung: Rosda.

Sukmadinata, N. S. (2012). Metode penelitian Pendidikan. Bandung: Remaja Rosdakarya.

Suwandi, B. d. (2008). Memahami Penelitian Kualitatif. Jakarta: Rineka Cipta.

Tafsir, A. (2010). Ilmu Pendidikan Dalam Perspektif Islam. Bandung: Rosda.

UU Sisidiknas. (2013). Bandung: Fokusmedia. 